\title{
In Search of the Necessary Conditions for Transforming the Chinese Reified Social Reality
}

\author{
Mingyue Wen \\ School of Government, Nanjing University, Nanjing, China \\ Email: mingyuewen@hotmail.com
}

How to cite this paper: Wen, M. Y. (2018). In Search of the Necessary Conditions for Transforming the Chinese Reified Social Reality. Open Journal of Political Science, $8,193-205$.

https://doi.org/10.4236/ojps.2018.82014

Received: January 6, 2018

Accepted: April 23, 2018

Published: April 26, 2018

Copyright (C) 2018 by author and Scientific Research Publishing Inc. This work is licensed under the Creative Commons Attribution International License (CC BY 4.0).

http://creativecommons.org/licenses/by/4.0/

(c) (i) Open Access

\begin{abstract}
A reified social reality is oppressive in essence and reactionary by nature. Transforming reified social realities is thus desirable, but what are the necessary conditions for effective transformation? The related literature has yet to furnish a basis to address this critical question. To generate theoretically meaningful and practically usable knowledge for theorists and practitioners, this paper analyzes a successful case of the transformation of a reified social reality in China in the early $20^{\text {th }}$ Century and reports a recent natural experiment basing on the findings of the aforementioned case analysis. The purposes are to identify the necessary conditions for effective transformation and to illustrate how the propositions basing on the fruitful experience reported could be applied to formulate strategies for solving similar problems in contemporary China. The principal finding of the case study is that pertinent political propositions, appropriate strategies, and effective operation mechanisms are the three necessary conditions for the occurrence of transformation of reified social reality. The principal finding of the natural experiment is that the three necessary conditions are indeed essential to enhancing the feasibility of the occurrence of transformation of the reified social reality in China in the $21^{\text {st }}$ Century. Research and policy implications are discussed.
\end{abstract}

\section{Keywords}

China, Human Growth and Development, Marxism, Optimal Governance, Theory-Building

\section{Introduction}

Researchers have noted that, while the economic development of the People's Republic of China (PRC) in the past three decades has been impressive, this achievement is accomplished by various serious social and political problems, 
such as inequality, inequity, epidemic corruption, and continual mass protests (Harwit, 2014; Zheng, 2012; Zheng, 2013). From a sociological-political perspective, these problems are inevitable. After all, social realities are often reified-trapped in vicious cycle of development.

The concepts of reification and transformation of social reality are delineated in Berger and Luckman's The Social Construction of Reality (Berger \& Luckman, 1966) and Hummel's The Bureaucratic Experience (Hummel, 1994). Reification means regarding something abstract as a material thing. According to the theory of social construction of reality depicted in the aforementioned books, members of a social system can be considered as social beings undertaking actions that objectify - that is, making their actions of value realization part of the social reality that they and others could observe. With repeated undertakings of the same actions, objectification, or the process of stabilizing the social reality, takes place. As the social values which enhance objectification prevail, other competing values would be marginalized and their respective social actions would be considered deviant and thus sanctioned. As time goes by, externalization occurs, through which members of the social system could no longer objectify due to reprimand and sanction, but to accept the reality as is and choose to go with the flow. When they find the externalized reality beyond their resistance, reification has occurred.

A reified social reality serves the well-beings of those who benefit from the externalized values and practices. But it limits choice options for others, thus circumscribing freedom, sabotaging actualization of human potentials, and making sustainable happiness unattainable. It also prevents the all-round development of all members of the social system, inclusive of the privileged class. A reified social reality is therefore oppressive in essence and reactionary by nature. As such, transforming reified social realities is more than desirable-it is a duty call to those who are committed to making their respective society a better place for all. However, a pending question must be addressed, of which is "What are the necessary conditions for effective transformation?"

Identification of necessary conditions for the occurrence of specific events is a critical pursuit, essential to social scientific theory-building. The propositions taking the causal form of "if not X, then not Y" or "if X, then Y is likely" would provide a basis for constructing more complex causal models embracing "given $\mathrm{X}$, and if $\mathrm{Y}$, then $\mathrm{Z}$ ". The propositions so generated could also be used to guide the devise of social action plans to mitigate problems in society. My literature review, unfortunately, has generated limited amount of relevant materials and research findings about transformation of reified social realities. A plausible explanation is that it is a macro-level political-sociological phenomenon, and thus could only be examined from a holistic perspective. Nevertheless, most contemporary researchers tend to, on the one hand, adopt the mono-disciplinary approach to examine the political or sociological aspects of reified reality's transformation and, on the other hand, apply the reduction a list approach to analyze 
messo- or micro-level phenomenon.

To generate theoretically meaningful and practically usable knowledge of transformation of reified social realities for Chinese theorists and practitioners, this study uses the scientific empiricist foundationalism (Kilduf, Mehraand, \& Dunn, 2011; Ketokivi \& Mantere, 2010) and the scientific instrumentalism (McGinnis, \& Ostrom, 2011; Mcgarth, 2007) approaches to analyze a successful case of transformation of reified social reality in China in the early $20^{\text {th }}$ Century. The purposes are to identify the necessary conditions for effective transformation and to illustrate how the propositions basing on the Chinese experience could be applied to formulate strategies for solving similar problems in the $21^{\text {st }}$ Century in China and in other developing countries.

\section{The Development of China at the Crossroads}

A reified social reality is in formation in the People's Republic of China (PRC). Before elaboration (see section 3), a brief introduction of modern Chinese history (Mabbett, 1985; Butterfield, 1982) is useful to readers not familiar with China's development. In brief, after the Communist Party of China (CPC) militarily defeated the Nationalist Party of China (NPC) in 1949 to establish PRC, it strived to build a revolutionary state basing on Marxist-Leninist principles. The pursuit was difficult because China in the early $20^{\text {th }}$ Century was a least-developed country with agrarian economy and had suffered from the imperialist Japanese invasion (1931-1945) and civil war (1946-1949), on top of Western imperialistic exploitation and suppression for more than a century.

In search of ways to rapidly modernize China, CPC had undergone trial use of the former Soviet Union development model and such indigenous strategies as the Great Leap Forward campaign (1958 to 1961). The 1959-1961 famine and the Sino-Soviet split (1960), however, halted the quest for rapid revolutionary development. Bureaucratization took place, inducing conflicts between the ideologues and pragmatists and creating room for political opportunists within the CPC elite circle to maneuver. Power struggle became endemic particularly during the Great Proletarian Cultural Revolution (1966-1969). To self-protect became a popular pursuit in these economic and political turbulent times.

Eventually, with the norms of pragmatism and Realpolitik well observed by the citizenry, the development of PRC ended in stalemate. Further, PRC became a distorted Marist-Leninist state characterized by political monism with all political, social, economic, and judicial powers monopolized by CPC members, who were primarily concerned with their own political survival and/or self-enrichment, rather than realization of Marxian values. Basing on field interviews with hundreds of state cadres in various parts of China, Chan and Chow had reported in 2007 that state cadres were in the process of transformation-transforming from power-wielders responsible for serving the citizenry to power-monopolists concerned with self-interest advancement (Chan, \& Chow, 2007). My field observation and interview conducted in the past three years in 
southern China have documented the same.

Economic backwardness and politicking were the main factors constraining China's development in the 1970s (Mabbett, 1985). After the de facto ruler of China, Mao Zedong, passed away in 1976, Deng Xiaoping subsequently became the new supreme leader. He redefined the essence of PRC, labeling it a country at the primary stage of development of socialism, with the mission of optimizing productivity for modernization. Under Deng's leadership, major economic reforms were launched to enhance progress. Such impressive achievements as becoming the second largest economy by nominal total GDP in the second decade of the $21^{\text {st }}$ century, however, are accompanied by such problems as epidemic corruption, outright organizational cheating, brutal abuse of human rights, and ongoing social unrests (Chan, \& Chow, 2007).

These problems are seemingly inevitable. Consider corruption. It has been endemic due to the institutional features of a distorted Marist-Leninist state-with the People's Congress as a "rubber-stamp" legislature, unchecked policy-making and implementation powers are vested in the state bureaucracy with self-serving state cadres being the wielders of political, social, economic, and judicial powers. Then, as PRC further develops economically, the corruption stakes increase exponentially-recent news reports on anti-corruption reveal that bribes received by township level cadres could amount to millions of US dollars, while bribes at ten million dollars for provincial level cadres are hardly atypical. Given that their average annual income is just around US $\$ 10,000$, state cadres inevitably find corruption irresistible. In this context, even though most state cadres and CPC members no longer subscribe to Marxian revolutionary values, they as power wielders are still committed to regime continuity, just because it enhances their self-enrichment (Butterfield, 1982).

Research has documented that the malfunctioning of the state bureaucracy has been a prime cause of various major economic, political, and social problems in PRC, undermining CPC's governance legitimacy (Zheng, 2012; Zheng, 2013; Chan, \& Chow, 2007). Inevitably, the CPC leadership has to repeatedly introduce such reform policies and measures as rule-of-law and sunshine practice to keep power wielders in check. Their effectiveness, however, is questionable, as such deadly sins of state administration as ineffectiveness and corruption still prevail, observable in all administrative organs, institutions, and state-owned enterprises (Caulfield, 2006).

After the $18^{\text {th }}$ Plenary Session (2012), the CPC leadership has intensified its efforts to curb corruption and abuse of authority. As a result, as plentiful public opinion surveys have shown, citizen political trust in the CPC leadership has increased (Zheng, 2013). Such an increase, however, is hardly an assurance that the citizenry would still support the regime when they have other options. One fundamental problem is that CPC has failed to refine its governance ideology to justify the Marxist-Leninist institutional arrangement of political monism, which now serves only the interests of power wielders, rather than collective interests of 
the 1.38 billion Chinese. Given that individualism and pragmatism have already taken root in PRC, many people inevitably find Marxian values irrelevant, political monism undesirable, and Western political-economic regime values attractive. This basic monism-individualism contradiction is the source of various challenges, which may trigger regime collapse (Chow, 2010).

As of today, however, the prime concerns of the CPC leadership merely revolve around the upgrading of PRC's overall capacity to face challenges that stem from globalization, such as intensifying global economic competition and rising international standards of quality of goods and services, as well as unchecked-marketization, hyper-consumerism, capital accumulation in monopolization, and citizen preference for Western style rule-of-law practices. The CPC leadership has yet to find ways to handle such deeper level challenges, such as some CPC members' lacking faith in communism and many citizens are receptive to such Western socio-political values as individualism and procedural democracy (Ogden, 2014). These challenges are threatening the legitimacy of CPC's monism (Gilley, 2008).

The aforementioned deeper level challenges are generating wide and far-reaching impacts on the course of PRC's development. At stake is CPC's governance, as regime collapse may suddenly take place, just as the former Soviet Union had experienced (Kux, 1990). At the crossroads, PRC could either continue her current development path to become Westernized and eventually experience regime collapse as the CPC leadership has noted (Wu, 2012) and as some researchers have predicted (Ogden, 2014; Gilley, 2008) or strive to transform herself into a socialist state with socio-economic and political developments guided by genuine Marxian political, social, and economic values. Reification of social reality, however, makes the desirable transformation difficult, if not impossible.

\section{The Reification of Social Reality in China}

In the case of China, the social reality has become reified, as almost all Chinese people find it unchangeable and beyond their resistance. In brief, research has already documented that self-serving has become an objectified reality in PRC since the 1960s and, as such, most Chinese (inclusive of CPC members) are concerned with optimizing personal interests, oftentimes disregarding the unethical outcomes of their self-serving behaviors (Chow, \& Luo, 2007). Given the prevalence of individualism and pragmatism, inevitably, exploitation, oppression, dishonesty, deceitfulness, and the like are endemic, while some power wielders would even subscribe to Machiavellianism (Chan, \& Chow, 2007; Chow, \& Luo, 2007). Thus, people from all walks of life find such a social reality beyond their resistance. In the state bureaucracy, genuine Marxists with revolutionary zeal and sense of responsibility are in social isolation, witnessing other cadres' abuses of authority for personal gains. They who try to exercise public authority with integrity would be penalized. Eventually, they also yield and focus 
on their personal well-being (Chow, \& Luo, 2007).

Self-serving contradicts the basic values of socialism. The reified social reality of individualism, human greed, irresponsibility, and realpolitik could erode CPC's governance legitimacy, even though some citizens support the CPC leadership (Yang, 2014). The Xi (Jinping) administration (2012-present) has strived to create political support by advocating "Chinese dreams" (Heberer, 2014). The effectiveness, however, has been questionable, as "Chinese dreams" could merely be individuals' dreams of self-enrichment (such as accumulating more wealth or migrating to the USA), which may further reinforce individualism. Seemingly, Western style democratization as forecasted by China watchers (Gilley, 2008) may soon become a reality. Yet, Western style democratization that takes place in a self-serving behavioral context with defective rule-of-law policy and checks-and-balances mechanisms would intensify realpolitik and eventually lead to political instability and even chaos. The self-serving and corrupt Nationalist regime (1911-1949) documented exactly that. In the $21^{\text {st }}$ Century, a loose-loose outcome for all the Chinese people is likely, unless the current reified reality can be transformed. Pragmatic reforms are in effect useless, as they could merely delay Western style democratization and subsequent chaos.

Reified social realities are oppressive and reactionary, and thus should be transformed. However, individuals attempting to change the reified reality by themselves would fail, often at great personal cost. After all, beneficiaries of the reified reality would not yield unless overwhelmed. Their resistance could be crucial and brutal. As such, reality transformation is in essence warfare. Successful transformation takes collective efforts to undertake strategic actions in massive scale and on a continuous basis. Could it happen in China?

\section{The Case of Reality Transformation in the $20^{\text {th }}$ Century}

Since a reified reality is man-made, it is thus transformable. Indeed, the Chinese modern history has shown that transformation of reified reality had occurred in 1921-1949. In other words, to address the aforementioned question of "Could it happen in China", the straightforward answer is "It did happen!"

As mentioned, in the early $20^{\text {th }}$ Century, China was an agricultural society. By then, all types of power monopolized by a handful of ruling elites, who did not hesitate to use brutal force to maintain their exploitative governance. To the have-nots, the social reality was reified. To the overwhelming majority of the people at the time, accepting the reality was inevitable. Then, Lenin's success in establishing a revolutionary state in 1917 had inspired some Chinese revolutionaries. CPC was then formed in 1921 with 50-plus members to organize proletariats to build a new nation-state for Chinese people to live with security, dignity, and decency. By then, the supply of workers as revolutionaries was scant, which was inevitable in an agrarian society. Further, citizen support to CPC was minimal, particularly after the Nationalist regime brutally suppressed CPC in April 1927, cutting the size of partisan membership from 60,000 to 10,000 . 
Safeguarding the CPC revolution was Mao Zedong, who first advocated a strategic approach to launch the proletariat revolution by establishing military bases in mountain areas with peasants as revolutionaries. His advocacy had two critical elements. First, by redefining peasants as revolutionaries, rather than disinterested parties or passive supporters, this redefinition was in essence an articulation of political propositions pertinent to the unique characteristics of the time, and was proven necessary to eventual success, because it changed the nature of CPC revolution from proletariat revolution to revolution by the have-nots and oppressed, who constituted the overwhelming majority of Chinese people. And second, the strategy to establish military bases in mountain areas in fact contradicted the Marxist-Leninist orthodox, which prescribed the strategy of proletariat revolution in cities. Yet, it enhanced CPC's survival. Mao Zedong's logic was based on dialectics, focusing on the fundamental contradictions in the Chinese society-while the oppressive class exploited and suppressed both peasants and workers, its reactionary strength was relatively weak in the vast territory of the agrarian China, thus creating room for CPC and its supporters to maneuver.

This unique contribution by Mao Zedong-provision of pertinent political propositions and revolutionary strategy-had helped CPC to materialize its revolutionary efforts. The Provisional Soviet Government was then established in the Jiangxi province in 1930, resolving the issue of survival. Nevertheless, due to the incongruence between the orthodox proletariat revolution approach and Mao's pragmatic revolutionary strategies, he was relieved from his leadership post in 1933. Afterwards, NPC made impressive military progress. CPC was eventually forced out, launching its 25,000-mile Long March in 1935. The Red Army was downsized from 80,000-plus to around 30,000 soldiers in an ambush as forecasted by Mao Zedong. The total dissatisfaction among stakeholders pushed him back to power.

Under his leadership, CPC adopted all available means to turn itself into a high performing organization. Effective operation mechanisms were devised. For stance, democratic centralism was institutionalized, of which made it possible for CPC members to directly give strategic development suggestions to the leadership for consideration. An example is CPC's decision to immediately dispatch 100,000 CPC troops to northeastern China after Japan surrendered in 1945. This was a strategic move that allowed CPC to consolidate its power base in that region, which was comparatively industrialized, vast in territory, and rich in food supply. The suggestion was made by a mid-level officer outside the power circle, but was still well received by the leadership. The 100,000 CPC troops eventually developed into a liberation army of about one million in just three years. It defeated Nationalists' 600,000-plus military forces in that region in just two months in 1948, and then joined the other CPC army divisions to liberate the whole country.

During the War of Resistance against Japanese Aggression (1937-1945), the 
CPC army had only outmoded rifles and inadequate food supply. CPC managed to prosper in this dark time by practicing democratic centralism and deploying the confiscation mechanism of "undertaking military actions to sustain war capacity" (by subduing opponents and then confiscating weaponry and related supplies). Afterwards, the confiscation mechanism was again used in the civil war period (1946-49). Further, with appealing revolutionary ideals (i.e., the pertinent political propositions of revolution by the have-nots and oppressed), successful economic reform in liberated areas to redistribute farm land and other means of production to poor peasants (the wealth redistribution strategy), and efficacious mass political education and effective propaganda (the united-fronts mechanism), CPC gained popular support, making it possible for CPC with only one million-plus troops to defeat Nationalists' four-million-plus military forces, which were well equipped with modern American weaponry. The establishment of PRC on 1 October 1949 signified the achievement of the transformation of the reified social reality.

The successful case reported above has highlighted the causality of effective reality transformation-pertinent political propositions, appropriate strategies, and effective operation mechanisms are crucial factors to success. By redefining proletariats in terms of income and harsh socio-political conditions, CPC made its pursuit a poor people revolution, thus creating massive political supports from people of all walks of life. The strategy to maneuver at the weak spot of reactionary forces allowed CPC to develop rapidly in the vast territory of countryside. The democratic centralism and confiscation mechanisms, among other things, effectively enhanced CPC's vitality. In short, The CPC case documents that pertinent political propositions, appropriate strategies, and effective operation mechanisms are the three necessary conditions for the occurrence of transformation of reified social reality, taking the causal form of "if not $\mathrm{X}$, then not $\mathrm{Y}$ " or "if $\mathrm{X}$, then $\mathrm{Y}$ is likely".

\section{The Feasibility of Chinese Reality Transformation in the $21^{\text {st }}$ Century}

In view of the facts that most Chinese people are now relatively well off and have internalized the values of individualism and pragmatism while many power wielders practice Machiavellian tactics as underscored in the preceding pages, it is reasonable to speculate that most Chinese people would not have the urge to engage in the reality transformation warfare in the $21^{\text {st }}$ Century. After all, both the intense politicization in the 1960s-1970s and economic reforms launched since 1978 had eroded PRC's ideological basis, making the citizenry unreceptive to CPC's political preaching and governance legitimacy.

Student responses in my classroom are revealing. In brief, when I demonstrated in the classroom how to apply principles of Marxism and Mao Zedong thinking to analyze contemporary public affairs issues, both undergraduate and graduate students got bored, while MPA students with job experience found my 
analysis irrelevant to their real world problem-solving. When my teaching revolved around the formulation of public policies to realize Marxian values, students considered it unnecessary or impractical. Then, when I discussed such problems as corruption and abuse of authority, they became enthusiastic, expressing resentment and support for wholesale institutional reform. All these furnish a basis to wonder if the contemporary Chinese citizenry may indeed be unreceptive to CPC's governance, (Zheng, 2012; Zheng, 2013) meaning that a necessary condition of regime collapse is in formation.

Nevertheless, a critical question remains to be addressed: Do Chinese people reprobate Marxism outright or do they merely reject propositions of classical Marxism as sermonized by the CPC propaganda machinery but still endorse genuine Marxian values? An incident is quite revealing-the 2008 Sichuan earthquake. The deadly earthquake had killed at least 69,000 people and left about 4.8 million people homeless. The disaster relief work received massive support, with volunteers flooding in consecutively and nationwide donation copiously generated. One academic study documented that almost all Chinese had revealed in the incident their compassionate nature and strong altruistic tendency, which genuine Marxian principles are based on (Chow, 2014). In other words, the overwhelming majority of the Chinese people may still be quite receptive to Marxian values and corresponding revolutionary propositions, and would strive to realize the Marxian ideals when objective conditions permit.

In order to confirm if Chinese people reject Marxian values outright, I had conducted a natural experiment in a public university in 2015-17. In brief, I taught different Chinese public administration courses taken by undergraduate and MA students. When analyzing fundamental causes of administrative problems, I did not mention such orthodox concepts as exploitative capitalism, oppressive imperialism, proletariat revolution, vanguard, dialectics, etc. Instead, basing on Marxian values, I redefined proletariats as vulnerable people of all ages and from all walks of life suffering from all sorts of social, political, and economic exploitation and oppression, such as school bullying, racial discrimination, abusive commercial behavior, sexual harassment, violation of citizen rights, manipulative consumerism, commercialization of human dignity, and emotional abuses in all types of social relationships.

Moreover, with reference to the literature on human development, I reported to the students that people are developmental, evolving from the primitive stage of being ignorant, incompetent, dependent, shortsighted, and self-centered to the developed stage of being knowledgeable, competent, independent, farsighted, and altruistic. I underscored that the core of human development is the evolution from social-psychological immaturity to maturity, measured in terms of selfishness and selflessness, respectively. Further, human beings and other animals are alike in that their various needs are driven by animal instincts. Those who could not control their animal instincts are inevitably selfish, deceitful, or even brutal, and vice versa. I also pointed out that selfishness is the basic cause of all 
types and forms of exploitation and suppression.

I then suggested to students that, basing on the above understanding, people could be classified as persons at the elementary level of development when they are selfish, no matter how knowledgeable, competent, independent, and farsighted they are. In contrast, those at the advance level of growth and development are altruistic. They are social-psychologically mature with self-discipline, strong urge to fulfill social responsibility, and compassion for other people and living creatures. In essence, they are transformed beings, even though they may still be relatively ignorant, incompetent, dependent, and shortsighted. More importantly, they are willing and eager to help make this a better world for all by extinguishing exploitation and suppression. However, as it takes various physiological, psychological, and socio-political factors to act in concert to effectuate transformation, human development is unavoidably a long and difficult process. As a result, most members of society are primarily social-psychologically immature. Such a collective immaturity in turn reinforces selfish behaviors in society, creating a vicious cycle of stagnant human development in China.

Furthermore, I assessed with the students in the classroom the contemporary need to establish a genuine government of the people, for the people, and by the people. I then analyzed how such a government could enhance such mechanisms as "optimal governance" for actively and effectively exercising public authority to mitigate problems of exploitation and suppression while promoting citizens' optimal growth and development. I used CPC in its heyday as an example to underscore the feasibility, practicality, and values of "optimal governance". In brief, basing on recent research findings (Zhou, \& Luo, 2016), I firstly highlighted that CPC could establish PRC all because of its unique value system, which was composed of three deep level core values-"genuine respects for others", "willingness to help the needed", and "co-development for co-prosperity". These values were advocated and realized by CPC between 1930s and 1950s, and were widely endorsed by the 400-million Chinese.

I then reported to students that CPC members' internalization of these values of respect, altruism, and co-development (hereafter RAC Values) had fostered their urge to contribute to the institutionalization of "optimal governance" which, basing on the application of public authority, functioned to promote people to mutually grow and develop. In the process, those who had a strong sense of social responsibility basing on the RAC Values would seek to create practical knowledge and develop new skills and techniques to optimize their performance and in turn their contribution to collective interests. As a result, even illiterate slaves could be nourished into medical doctor and military commander, while poor peasants and unskilled workers became competent professionals. They underwent a transformation and then acted in concert to create miracles-for example, CPC had only around 50,000 Red Army in 1937 but managed to militarily defeat the 4 million-plus Nationalist troops in the 1947-1949 civil war. I then concluded my reporting by asking the students a 
critical question: how could the Chinese people in the $21^{\text {st }}$ Century strive to make this a better world for all?

The findings of my experiment are remarkably amazing. First, when Marxian terms were not used in our teaching, all the students showed genuine interest in various critical socio-economic and political issues and problems in contemporary China. Obviously they are tired of official propaganda and preaching, even though they are concerned citizens. Second, be they from well-off or have-not families, they all expressed their resentment of exploitation and suppression, as they themselves had had experienced different types and forms of exploitative and/or oppressive acts in the past. Third, all students considered selfishness undesirable and human development valuable. They also endorsed the "optimal governance" proposition and discussed among themselves how such operation mechanism could be articulated in the $21^{\text {st }}$ Century. And fourth, once the students realized that there were various types and forms of exploitation and oppression in existence, they actively brainstormed to generate all kind of suggestions about institutional reform, policy reformulation, cultural norm modification, and specific action plans. Interestingly, their suggestions belong to the Marxian tradition, even though their wordings used were non-Marxian.

My experiment reveals that, by focusing on people as vulnerable beings suffering from selfishness-induced exploitation and suppression, students could understand people's alienation from freedom and development. Further, they self-consciously affirmed the need to act collectively in order to transform human selfishness so as to end exploitation and suppression. For sure, their full rejection of individualism and pragmatism could hardly be materialized overnight. But the experiment shows that Marxian values are still relevant in the distorted Marxist-Leninist state like PRC and that internalization of Marxian values is feasible even in the current reified social reality, because people are developmental. Furthermore, my experiment shows that pertinent political propositions, appropriate strategies, and effective operation mechanisms are indeed three necessary conditions for enhancing the feasibility of the occurrence of transformation of reified social reality in China in the $21^{\text {st }}$ Century.

\section{Concluding Remarks}

All in all, the study documents that pertinent political propositions, appropriate strategies, and effective operation mechanisms are the three necessary conditions for the occurrence of transformation of reified social reality. Social and political reformers committed to transforming the reified social reality in the respective countries should thus focus on the creation of these three necessary conditions. It should be noted that reality transformation is inevitably a long process. It took CPC 28 years in the $20^{\text {th }}$ Century to accomplish the transformation mission. It is thus reasonable to expect that achieving this mission in PRC in the $21^{\text {st }}$ Century will be as time-consuming. After all, vulnerable people in contemporary China face the critical problems of ideological confusion and unawareness of the need 
to enhance human growth and development.

The mitigation of these critical problems will take time. In the case of China, the first step for committed Chinese reality transformers to take is to affirm the Chinese people's receptivity of genuine Marxian values. The experiment reported above shows that educated young people are indeed receptive and are motivated to help transform the reified social reality if the genuine societal values are rediscovered in wordings and expressions pertinent to the temporary context. The next step is for the CPC leadership to officially reword Marxian propositions, to systematically design appropriate strategies, and to practically devise effective mechanisms for the desirable effectuation of reality transformation. These are demanding jobs. Hopefully, the mission of revitalization of Marxist China could be more timely accomplished, as it could generate valuable experience and inspiration for all vulnerable people everywhere to strive to collectively enhance transformation of reified realities in their respective countries. Finally, as pertinent political propositions that are adaptive to contemporary societal conditions in different countries with different milieu are the most important factor to transformation success, trans-disciplinary contributions from sociologists, political scientists, and area study specialists are crucial.

\section{References}

Berger, P., \& Luckman, T. (1966). The Social Construction of Reality: A Treatise in the Sociology of Knowledge. London: Penguin Books.

Butterfield, F. (1982). China Alive in Bitter Sea. Times Book.

Caulfield, J. L. (2006). Local Government Reform in China: A Rational Actor Perspective. International Review of Administrative Sciences, 72, 253-267. https://doi.org/10.1177/0020852306064613

Chan, H. S., \& Chow, K. W. (2007). Public Management and Policy in Western China: Metapolicy, Tacit Knowledge, and Implications. American Review of Public Administration, 37, 479-498. https://doi.org/10.1177/0275074006297552

Chow, K. W. (2010). Chinese State Bureaucracy and Democratization: Contradictions and Strategization. Public Organization Review, 10, 255-274.

Chow, K. W. (2014). Altruism in Chinese Emergency Management: The Case of Wenchuan Earthquake. In A. Farazmand, (Ed.), Crisis and Emergency Management: Theory and Practice, (2nd Edition, pp. 585-596). Boca Raton: CRC Press.

Chow, K. W., \& Luo, L. Q. (2007). Rationalizing Public Organizations in Western China: Contending Approaches and Conflicting Logics. Public Organization Review, 7, 69-91.

Gilley, B. (2008). Legitimacy and Institutional Change: The Case of China. Comparative Political Studies, 41, 259-284. https://doi.org/10.1177/0010414007308020

Harwit, E. (2014). The Rise and Influence of Weibo (Microblogs) in China. Asian Survey, 54, 1059-1087. https://doi.org/10.1525/as.2014.54.6.1059

Heberer, T. (2014). China in 2013: The Chinese Dream's Domestic and Foreign Policy Shifts. Asian Survey, 54, 113-128. https://doi.org/10.1525/as.2014.54.1.113

Hummel, R. P. (1994). The Bureaucratic Experience (4th edition). New York City: St. Martin's Press.

Ketokivi, M., \& Mantere, S. (2010). Two Strategies for Inductive Reasoning in Organiza- 
tional Research. Academy of Management Review, 35, 315-333. https://doi.org/10.5465/AMR.2010.48463336

Kilduf, M., Mehraand, A., \& Dunn, M. B. (2011). From Blue Sky Research to Problem Solving: A Philosophy of Science Theory of New Knowledge Production. Academy of Management Review, 36, 297-317.

Kux, S. (1990). Soviet Federalism. Problems of Communism, 60, 1-20.

Mabbett, I. (1985). Modern China: The Mirage of Modernity. New York City: St. Martin’s Press.

Mcgarth, R. G. (2007). No Longer a Stepchild: How the Management Field Can Come into Its Own. Academy of Management Journal, 50, 1365-1378. https://doi.org/10.5465/AMJ.2007.28166144

McGinnis, M. D., \& Ostrom, E. (2011). Reflections on Vincent Ostrom, Public Administration, and Polycentricity. Public Administration Review, 72, 15-25. https://doi.org/10.1111/j.1540-6210.2011.02488.x

Ogden, S. (2014). Will China Democratize? The China Quarterly, 19, 864-865. https://doi.org/10.1017/S0305741014000794

Wu, Z. (2012). Hu Warns Successors over "Peaceful Evolution". Asia Times Online. http://www.atimes.com/atimes/China/NA11Ad02.html

Yang, Z. (2014). Do Chinese People Trust Their Local Government, and Why? Problems of Post-Communism, 61, 31-44. https://doi.org/10.2753/PPC1075-8216610303

Zheng, Y. N. (2012). China in 2011: Anger, Political Consciousness, Anxiety, and Uncertainty. Asian Survey, 52, 28-41. https://doi.org/10.1525/as.2012.52.1.28

Zheng, Y. N. (2013). China in 2012: Troubled Elite, Frustrated Society. Asian Survey, 53, 162-175. https://doi.org/10.1525/as.2013.53.1.162

Zhou, J. W., \& Luo, S. (2016). On the Necessary Regression of the Value of Mao Zedong Thinking as a Methodology. Innovation, 10, 23-39. (In Chinese) 